\title{
Caged trans-4-hydroxy-2-nonenal
}

Robert G. Brinson, Paul B. Jones*

Department of Chemistry, Wake Forest University, Winston-Salem, NC 27109.

jonespb@wfu.edu

Supporting Information

Experimental procedures and characterization data for new compounds 2

Characterization and 2-D NMR data for 10a 5

References for Supporting Information 10 
General: Unless otherwise indicated, all reagents and solvents were obtained commercially and used without further purification. Melting points were measured on a Meltemp II apparatus and are uncorrected. Infrared spectra were measured on a Genesis II FTIR (Mattson Instruments) from samples on $\mathrm{NaCl}$ discs. Thin-layer chromatography was performed on silica gel ( $250 \mu \mathrm{m}$ thickness doped with fluorescein) unless otherwise indicated. The chromatograms were visualized with UV light $(254 \mathrm{~nm}$ or $365 \mathrm{~nm})$. Column chromatography was performed using silica gel $(60 \AA) .{ }^{1} \mathrm{H}$ and ${ }^{13} \mathrm{C}$ NMR spectra were run on a Bruker $300 \mathrm{MHz}$ or $500 \mathrm{MHz}$ NMR spectrometer. Photochemical reactions were conducted with either a $450 \mathrm{~W}$ medium pressure $\mathrm{Hg}$ lamp and a uranium oxide doped glass filter (366nm) or in a Rayonet reactor equipped with sixteen Hg lamps set to isolate the $419 \mathrm{~nm}$ line.

Synthesis of 1-bromo-2-nonen-4-ol 8: To a solution of 4-bromocrotonaldehyde ${ }^{1}$ (53.7 mmol) in THF $(80 \mathrm{mM}, 671 \mathrm{~mL})$ cooled to $0^{\circ} \mathrm{C}$ was added dropwise pentyl magnesium bromide (1.15 eq., $61.76 \mathrm{mmol})$ via an addition funnel. The reaction mixture turned a deep yellow color after fifteen minutes. The reaction was quenched with water $(200 \mathrm{~mL})$, extracted with ethyl acetate $(4 \mathrm{x}, 300 \mathrm{~mL})$, dried with $\mathrm{MgSO}_{4}$, and concentrated in vacuo to give a pale brown oil $(9.80 \mathrm{~g}, 83 \%)$. ${ }^{1} \mathrm{H}$ NMR $\left(300 \mathrm{MHz}, \mathrm{CDCl}_{3}\right) \delta 0.87-0.91(\mathrm{~m}, 3 \mathrm{H})$, $1.22-1.44(\mathrm{~m}, 6 \mathrm{H}), 1.49-1.54(\mathrm{~m}, 2 \mathrm{H}), 1.57$ (bs, $1 \mathrm{H}) 3.96(\mathrm{~d}, J=7.2 \mathrm{~Hz}, 2 \mathrm{H}), 4.11-4.18$ $(\mathrm{m}, 1 \mathrm{H}), 5.79(\mathrm{dd}, J=15.3,6.0 \mathrm{~Hz}, 1 \mathrm{H}), 5.91(\mathrm{dt}, J=15.3 \mathrm{~Hz}, 1 \mathrm{H}) .{ }^{13} \mathrm{C} \mathrm{NMR}(75 \mathrm{MHz}$, $\left.\mathrm{CDCl}_{3}\right) \delta$ 138.1, 126.4, 71.6, 36.9, 32.1, 31.6, 24.9, 22.5, 13.9. Anal. calcd for $\mathrm{C}_{9} \mathrm{H}_{16} \mathrm{OBr}$ : C, 48.88; H, 7.75; Br, 36.13. Found: C, 49.13; H, 7.86; Br, 35.86.

Synthesis of 1-allyloxy-9,10-anthraquinone. ${ }^{2}$ To a solution of 1-hydroxy-9,10anthraquinone $(2.23 \mathrm{mmol})$ in 2:1 THF:DMF $(0.106 \mathrm{M}, 21 \mathrm{ml})$ was added TBAF $(3.3 \mathrm{eq}$, $7.36 \mathrm{mmol}$ ). Allyl bromide was then added to the dark purple solution. The reaction mixture was stirred for 48 hours and was considered complete when the reaction mixture had turned a bright yellow color. The crude product was washed with water $(20 \mathrm{ml})$ and extracted with EtOAc $(2 \mathrm{x}, 30 \mathrm{ml})$. The organic extracts were combined and washed with more water $(2 \mathrm{x}, 60 \mathrm{ml})$, dried with $\mathrm{MgSO}_{4}$, and concentrated in vacuo. The crude product was recrystallized from $\mathrm{MeOH}$ to give yellow needles $(560.0 \mathrm{mg}, 95 \%)$. ${ }^{1} \mathrm{H}$ NMR (300 $\left.\mathrm{MHz}, \mathrm{CDCl}_{3}\right) \delta 4.78(\mathrm{dt}, J=4.7,1.7 \mathrm{~Hz}, 2 \mathrm{H}), 5.41(\mathrm{dq}, J=10.6,1.5 \mathrm{~Hz}, 1 \mathrm{H}), 5.69(\mathrm{dq}, J$ $=17.3,1.5 \mathrm{~Hz}, 1 \mathrm{H}), 6.10-6.22(\mathrm{~m}, 1 \mathrm{H}), 7.33(\mathrm{dd}, J=8.7,0.9 \mathrm{~Hz}, 1 \mathrm{H}), 7.67-7.82(\mathrm{~m}, 3 \mathrm{H})$, $7.98(\mathrm{dd}, J=7.7,0.9 \mathrm{~Hz}, 1 \mathrm{H}), 8.22-8.30(\mathrm{~m}, 2 \mathrm{H})$.

Synthesis of 2-allyl-1-hydroxy-9,10-anthraquinone: The compound was prepared using a modification of the method of Murty et al. ${ }^{1}$ A suspension of 1-allyloxyanthraquinone (16.5 mmol) in 1-butanol $(40 \mathrm{mM}, 411 \mathrm{ml})$ in a 3 neck flask was sparged for 2 hours with argon via a needle through a septum. Glucose (5 eq., $82.5 \mathrm{mmol}$ ) was then added under a steady stream of Ar. The yellow-orange reaction mixture was warmed to $80{ }^{\circ} \mathrm{C}$ for 10 minutes while stirring, after which a sparged saturated solution of $\mathrm{NaHCO}_{3}$ (4 eq, 66.0 mmol) was added via syringe. The reaction mixture was refluxed, at which temperature the starting material fully dissolved. During the course of the reaction at reflux, the reaction mixture turned from yellow orange to red and finally black. The reaction was considered complete via TLC (9:1 hexanes:EtOAC) after 110 minutes; the flask was opened to air, $1 \mathrm{~N} \mathrm{HCl}(100 \mathrm{ml})$ was added, and the reaction mixture was allowed to cool 
slowly to room temperature and then was further cooled to $0{ }^{\circ} \mathrm{C}$ using an ice water bath. The yellow precipitate was filtered via vacuum filtration and washed with water $(50 \mathrm{ml}$, $3 \mathrm{x})$ to give a yellow-orange powder $(4.0 \mathrm{~g}, 92 \%)$. ${ }^{1} \mathrm{H} \mathrm{NMR}\left(300 \mathrm{MHz}, \mathrm{CDCl}_{3}\right) \delta 3.52(\mathrm{~d}$, $J=6.4 \mathrm{~Hz}, 2 \mathrm{H}), 5.13-5.19(\mathrm{~m}, 2 \mathrm{H}), 5.95-6.09(\mathrm{~m}, 1 \mathrm{H}), 7.53(\mathrm{~d}, J=7.7 \mathrm{~Hz}, 1 \mathrm{H}), 7.75-$ $7.82(\mathrm{~m}, 3 \mathrm{H}), 8.25-8.30(\mathrm{~m}, 2 \mathrm{H}), 12.98(\mathrm{~s}, 1 \mathrm{H})$.

Synthesis of 1-hydroxy-2-propyl-9,10-anthraquinone 6: To a solution of 2-allyl-1hydroxy-9,10-anthraquinone (13.6 mmol) in 2:1 THF:MeOH $(0.1 \mathrm{M}, 136 \mathrm{ml})$ was added $3 \% \mathrm{Pd} / \mathrm{C}(720 \mathrm{mg})$. The resulting suspension was sparged for 10 minutes with Ar via a needle, sparged for 5 minutes with $\mathrm{H}_{2}$ via a needle, and finally a $\mathrm{H}_{2}$ balloon was attached via needle through a septum. The reaction was considered complete via NMR analysis after 2 hours. The crude mixture was filtered through celite and concentrated in vacuo to give a yellow solid (3.60 g, 99\%). Spectroscopic data matched that reported in the literature. ${ }^{3}{ }^{1} \mathrm{H}$ NMR $\left(300 \mathrm{MHz}, \mathrm{CDCl}_{3}\right) \delta 1.01(\mathrm{t}, J=7.4 \mathrm{~Hz}, 3 \mathrm{H}), 1.72$ (br. Sextet, $J=$ $7.5 \mathrm{~Hz}, 2 \mathrm{H}), 2.75(\mathrm{t}, J=7.9 \mathrm{~Hz}, 2 \mathrm{H}), 7.54(\mathrm{~d}, J=7.7 \mathrm{~Hz}, 1 \mathrm{H}), 7.77-7.83(\mathrm{~m}, 3 \mathrm{H}), 8.27-$ $8.35(\mathrm{~m}, 2 \mathrm{H}), 13.01(\mathrm{~s}, 1 \mathrm{H})$.

Synthesis of 1-(4-hydroxy-2-nonenyloxy)-2-propyl-9,10-anthraquinone 1: To a solution of 1-hydroxy-2-propyl-9,10-anthraquinone (5.26 mmol) in 2:1 THF:DMF (53 $\mathrm{mL}, 0.1 \mathrm{M}$ ) was added TBAF (1eq, $5.26 \mathrm{mmol})$. 1-Bromo-2-nonen-4-ol (0.5eq, 2.62 mmol) was added to the dark purple solution. The reaction mixture was stirred at room temperature for 5 hours and was considered complete by TLC (9:1 hexanes:EtOAc). The reaction was quenched with water $(50 \mathrm{~mL})$, extracted with EtOAc $(3 \mathrm{x}, 50 \mathrm{~mL})$, dried with $\mathrm{MgSO}_{4}$, and concentrated in vacuo. The crude product was chromatographed on silica (9:1 hexanes:EtOAc) and recystrallized from acetic acid and water to give a pale yellow powder $(683.0 \mathrm{mg}, 64 \%)$. mp: 94.0-95.0 ${ }^{\circ} \mathrm{C}$. IR $\left(\mathrm{NaCl}, \mathrm{cm}^{-1}\right) 3683,3610,3447$, 3019, 2960, 2930, 2858, 1727, 1690. ${ }^{1} \mathrm{H}$ NMR (300 MHz, $\left.\mathrm{CDCl}_{3}\right) \delta 0.88-0.92(\mathrm{~m}, 3 \mathrm{H})$, $1.00(\mathrm{t}, J=7.4 \mathrm{~Hz}, 3 \mathrm{H}), 1.25-1.59(\mathrm{~m}, 8 \mathrm{H}), 1.65(\mathrm{bs}, 1 \mathrm{H}) 1.63-1.76(\mathrm{~m}, 2 \mathrm{H}), 2.76(\mathrm{t}, J=$ $7.7 \mathrm{~Hz}, 2 \mathrm{H}), 4.18-4.25(\mathrm{~m}, 1 \mathrm{H}), 4.54(\mathrm{~d}, J=5.8 \mathrm{~Hz}, 2 \mathrm{H}), 5.93(\mathrm{dd}, J=15.5,6.0 \mathrm{~Hz}, 1 \mathrm{H})$, 6.10 (dtd, $J=15.5,5.8,0.9 \mathrm{~Hz}, 1 \mathrm{H}), 7.62 \mathrm{~Hz}(\mathrm{~d}, J=7.9 \mathrm{~Hz}, 1 \mathrm{H}), 7.72-7.81(\mathrm{~m}, 2 \mathrm{H}), 8.09$ $(\mathrm{d}, J=7.9 \mathrm{~Hz}, 1 \mathrm{H}) .8 .23-8.29(\mathrm{~m}, 2 \mathrm{H}) .{ }^{13} \mathrm{C} \mathrm{NMR}\left(75 \mathrm{MHz}, \mathrm{CDCl}_{3}\right) \delta 183.1,182.8,157.4$, 145.4 , 137.3, 135.6, 134.8, 134.1, 133.7, 133.4, 132.6, 137.2, 126.6, 126.0, 125.8, 123.5, 74.3, 72.2, 37.1, 32.5, 31.7, 25.0, 23.3, 22.6, 14.1, 14.0. HRMS calcd for $\mathrm{C}_{26} \mathrm{H}_{30} \mathrm{O}_{4} \mathrm{Na}^{+}$: 429.203628. Found: 429.20143. Anal. calcd for $\mathrm{C}_{26} \mathrm{H}_{30} \mathrm{O}_{4}$ : C, 76.82; H, 7.44. Found: C, 76.54; H, 7.44.

General Aerobic Procedure for NMR photolysis of 1: A stock solution of 1 (50 mg, $0.123 \mathrm{mmol}$ ) was prepared by dissolving 1 in $\mathrm{CD}_{3} \mathrm{OD}$ or $\mathrm{CD}_{3} \mathrm{CN}(2.460 \mathrm{~mL}, 40 \mathrm{mM})$ with mesitylene $(0.8 \mathrm{eq}, 0.0984 \mathrm{mmol})$. A sample was made up by diluting a portion of the stock solution to the desired concentration with $\mathrm{CD}_{3} \mathrm{OD}: \mathrm{D}_{2} \mathrm{O}: \mathrm{CD}_{3} \mathrm{CO}_{2} \mathrm{D}$ (800 uL) or $\mathrm{CD}_{3} \mathrm{CN}: \mathrm{D}_{2} \mathrm{O}: \mathrm{CD}_{3} \mathrm{CO}_{2} \mathrm{D}$ in a $5 \mathrm{~mL}$ conical flask. A 0 hour NMR was then taken with a relaxation delay of $5 \mathrm{sec}$. The integrations of the aryl methylene hydrogens $(\delta 2.75,2 \mathrm{H})$ on the propyl chain for 1 were compared to the aryl hydrogens $(\delta 6.78,3 \mathrm{H})$ on mesitylene. The sample was then irradiated at $\lambda>350 \mathrm{~nm}$ ( $\mathrm{Hg}$ medium pressure lamp (MPL), uranium oxide filter or Rayonet reactor with $419 \mathrm{~nm}$ lamps) with an $\mathrm{O}_{2}$ balloon attached via a needle and septum. 1 was consumed after 2 hours (MPL) or 2.5 hours (419nm). A 
NMR was then taken on the sample with a relaxation delay of 10.5 seconds. The integrations of the aryl hydrogens $(\delta$ 6.78) of mesitylene were compared against the aldehyde signal $(\delta 9.55,1 \mathrm{H})$ of 4 -HNE, the upfield vinyl signals of $\mathbf{1 0}(\delta 6.05-6.10,1 \mathrm{H})$, and the upfield vinyl signals of $9(\delta 5.61,1 \mathrm{H})$. After $\mathrm{D}_{2} \mathrm{O}(200 \mathrm{uL})$ and $\mathrm{CD}_{3} \mathrm{COOD}(200$ $\mathrm{uL}$ ) was added to the sample, it was allowed to sit overnight before a final NMR was run (relaxation delay 10.5 seconds). See Table 1 in article for NMR yields with respective conditions.

Aerobic photolysis of 1 at 419nm followed by photolysis with MPL: A flask was charged with $640 \mu \mathrm{l}$ of $\mathrm{CD}_{3} \mathrm{OD}$ and $160 \mu \mathrm{L}$ of a $50 \mathrm{mM}$ stock solution of 1 . Following removal of an aliquot for a 0 hour NMR (relaxation time $=5 \mathrm{~s}$ ), the resulting solution was irradiated (Rayonet Reactor, $419 \mathrm{~nm}$ lamps) for 2.5 hours, stirring vigorously, with an $\mathrm{O}_{2}$ balloon attached via a needle through a septum. NMR analysis (relaxation time $=10.5 \mathrm{~s}$ ) revealed a $28 \%$ yield of $4-\mathrm{HNE}$ and a mixture of 10a-like NMR vinyl signals. This sample was then irradiated ( $\mathrm{Hg}$ medium pressure arc lamp, uranium oxide filter) for another two hours, stirring vigorously, with a $\mathrm{O}_{2}$ balloon attached via a needle through a septum. Post photolysis nmr analysis (relaxation delay $=10.5 \mathrm{~s}$ ) revealed a $90 \%$ yield of 4 HNE.

General Aerobic Preparative Procedure for photolysis of 1: In X:1 MeOH: $\mathrm{H}_{2} \mathrm{O}$ or MeCN: $\mathrm{H}_{2} \mathrm{O}(1 \mathrm{mM}$ or $10 \mathrm{mM}) 1(100 \mathrm{mg}, 0.246 \mathrm{mmol})$ was dissolved in a $50 \mathrm{~mL}$ round bottom flask. A septum was attached to the flask with an $\mathrm{O}_{2}$ balloon via a needle. The sample was irradiated at $\lambda>350 \mathrm{~nm}$ ( $\mathrm{Hg}$ medium pressure arc lamp, uranium oxide filter or Rayonet Reactor $419 \mathrm{~nm}$ lamps), stirring vigorously. After three hours, the sample was rotovapped to near dryness. An additional $10 \mathrm{ml}$ of distilled water was added, and the flask was rotovapped again to near dryness. The aqueous layer was pipetted out; the orange-yellow solid was washed with distilled water $(5 \mathrm{ml})$ and dried in vacuo. The aqueous layer containing 4-HNE was washed with brine, extracted with $\mathrm{CHCl}_{3}(5 \mathrm{x}, 30$ $\mathrm{mL}$ ), and concentrated in vacuo. See Table 1 and text in article for isolated yields with respective conditions.

General Anaerobic Preparative Procedure for photolysis of 1: In $\mathrm{MeOH}(10 \mathrm{mM}$, $24.6 \mathrm{ml}) 1$ (100 mg, 0.246mmol) was dissolved. This resulting yellow solution was freeze:pumped:thawed (3x) and then irradiated at $\lambda>350 \mathrm{~nm}(\mathrm{Hg}$ medium pressure arc lamp, uranium oxide filter or Rayonet Reactor $419 \mathrm{~nm}$ lamps), stirring vigorously. After 5 hours, the sample was concentrated in vacuo. The resulting orange-yellow solid was stirred three times in $10 \mathrm{ml}$ distilled water for 1 hour after which the solid was dried in vасио. The aqueous layers were combined, washed with brine, and extracted with $\mathrm{CHCl}_{3}$ $(5 \mathrm{x}, 40 \mathrm{ml})$. See Table 1 and text in article for isolated yields with respective conditions. 


\section{Spectroscopic Data for 10a}

10a: pale yellow-orange solid; IR $\left(\mathrm{NaCl}, \mathrm{cm}^{-1}\right) 3428,3019,2962,2932,1671 .{ }^{1} \mathrm{H}$ NMR $\left(300 \mathrm{MHz}, \mathrm{CDCl}_{3}\right) \delta 0.91-0.98(\mathrm{~m}, 6 \mathrm{H}), 1.25-1.65(\mathrm{~m}, 11 \mathrm{H}), 2.56-2.71(\mathrm{~m}, 2 \mathrm{H}), 3.02(\mathrm{~s}$, $3 \mathrm{H}) 4.30-4.35(\mathrm{~m}, 1 \mathrm{H}), 6.04-6.11(\mathrm{~m}, 1 \mathrm{H}), 6.17(\mathrm{~d}, J=4.7 \mathrm{~Hz}, 1 \mathrm{H}), 6.23-6.30(\mathrm{dd}, J=$ 15.6, 5.5 Hz, 1H), 7.24-7.26 (m, 1H), 7.49-7.62 (m, 3H), 7.80-7.85 (m, 1H), 8.12-8.15 $(\mathrm{dd}, J=7.4,1.3 \mathrm{~Hz}, 1 \mathrm{H}) .{ }^{13} \mathrm{C}$ NMR $\left(75 \mathrm{MHz}, \mathrm{CDCl}_{3}\right) \delta 184.7,148.8,139.0,137.4,135.8$, 133.0, 131.5, 130.3,130.0, 129.3, 127.7, 125.00, 124.99, 122.9, 119.6, 92.14, 92.11, 71.8, 49.3, 37.0, 31.8, 31.7, 29.3, 25.0, 22.6, 22.5, 14.0. HRMS calc'd for $\mathrm{C}_{26} \mathrm{H}_{32} \mathrm{O}_{5} \mathrm{Na}^{+}: 459.21203$. Found: 459.21647 .

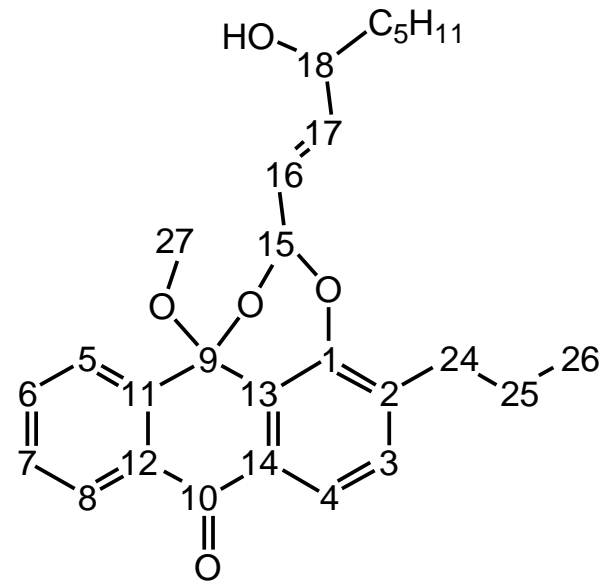

\begin{tabular}{|c|c|c|}
\hline & $\mathrm{H}$ & $13 \mathrm{C}$ \\
\hline & - & 148.8 \\
\hline 2 & - & 135.8 \\
\hline 5 & $7.83 \mathrm{~m}$ & 125.00 \\
\hline & - & 92.14 \\
\hline 11 & - & 137.4 \\
\hline 13 & - & 122.9 \\
\hline 15 & - & 92.11 \\
\hline 16 & $6.08 \mathrm{~m}$ & 124.99 \\
\hline 17 & $6.26 \mathrm{dd}$ & 139.0 \\
\hline 18 & $4.33 \mathrm{~m}$ & 71.8 \\
\hline 27 & $3.02 \mathrm{~s}$ & 49.3 \\
\hline
\end{tabular}

Important diagnostic signals are listed above for 10a.

Below are the ${ }^{13} \mathrm{C}$ and $2 \mathrm{D}$ data for 10a. 


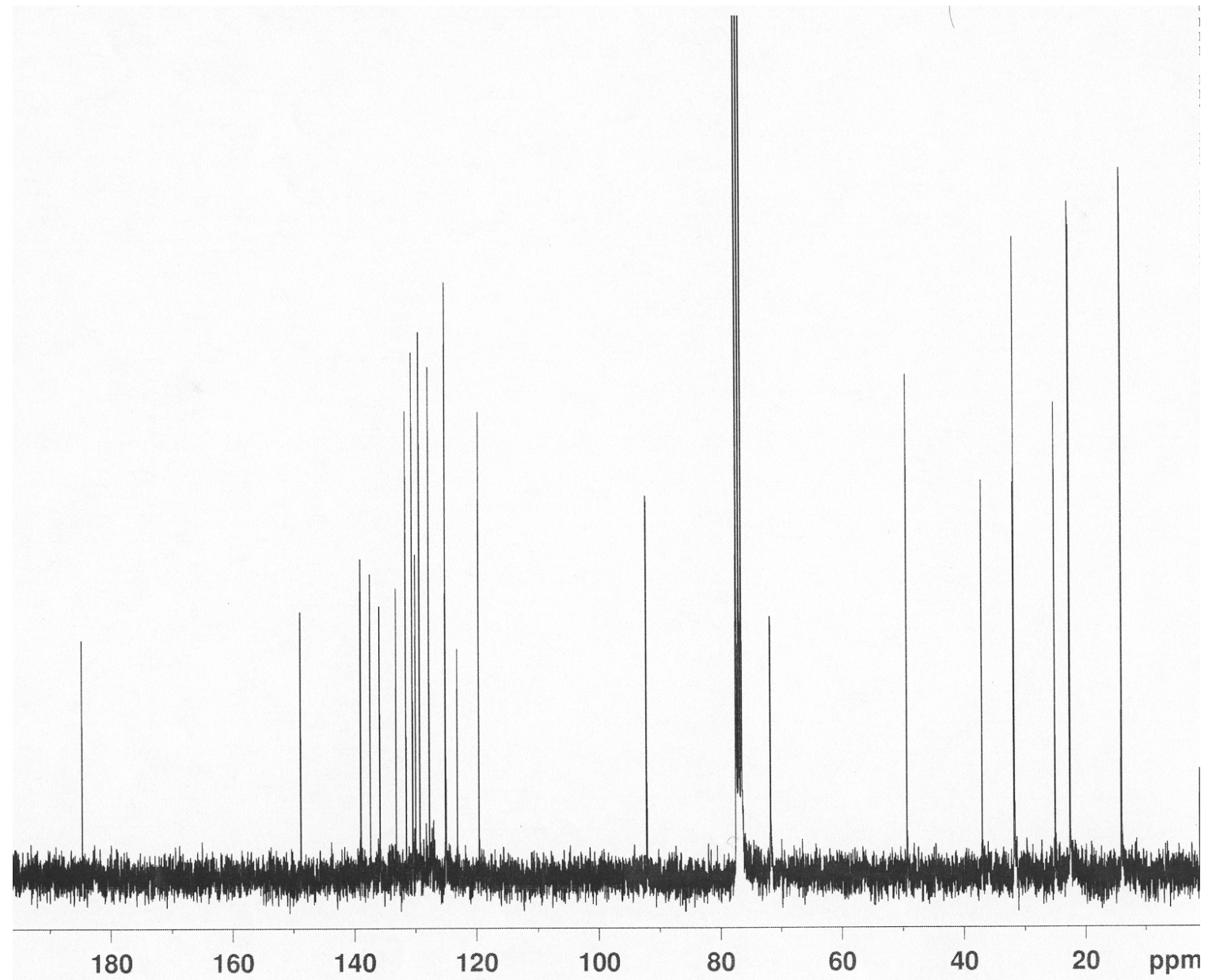

${ }^{13} \mathrm{C}$ for $\mathbf{1 0 a}$ 


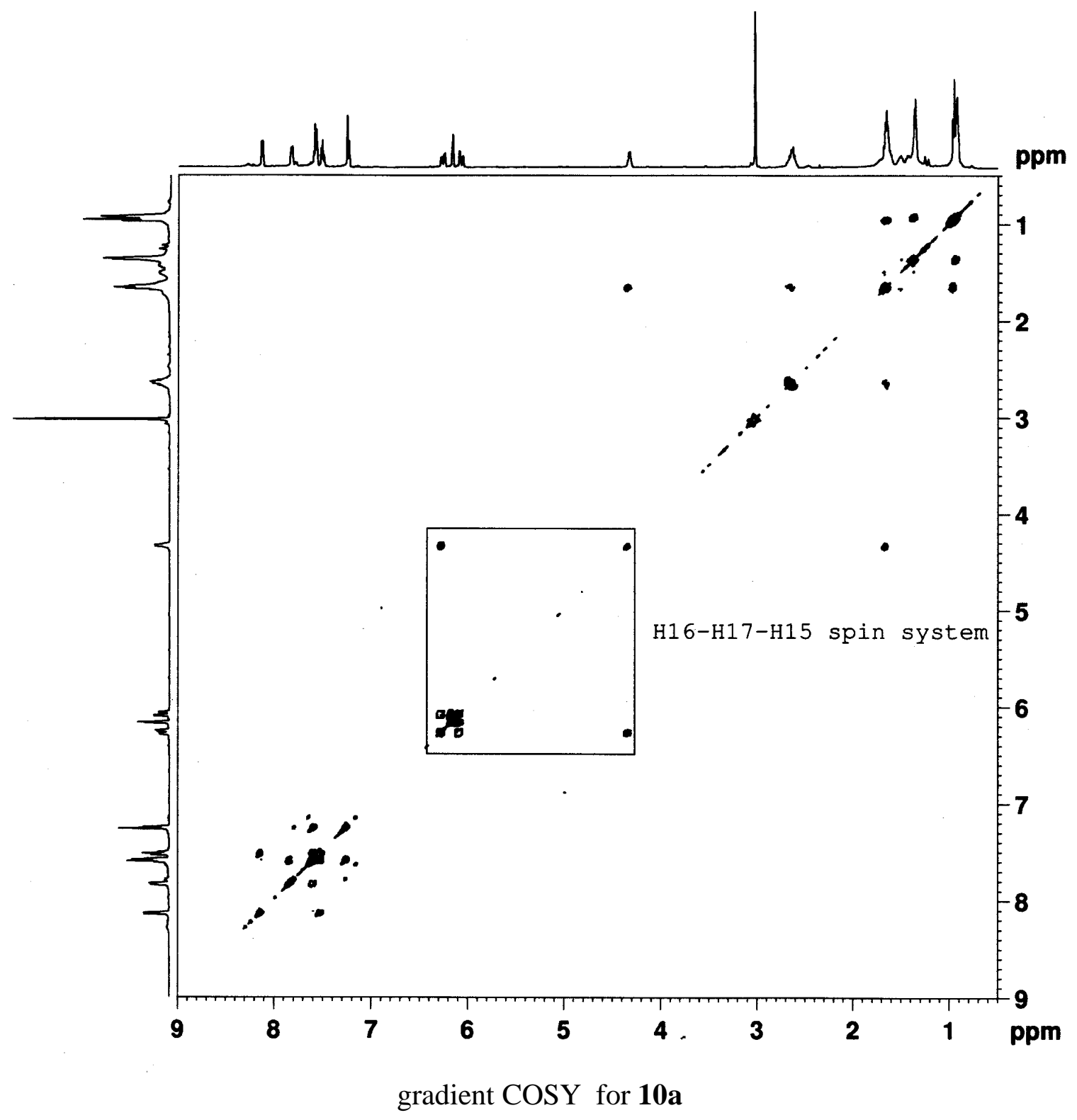




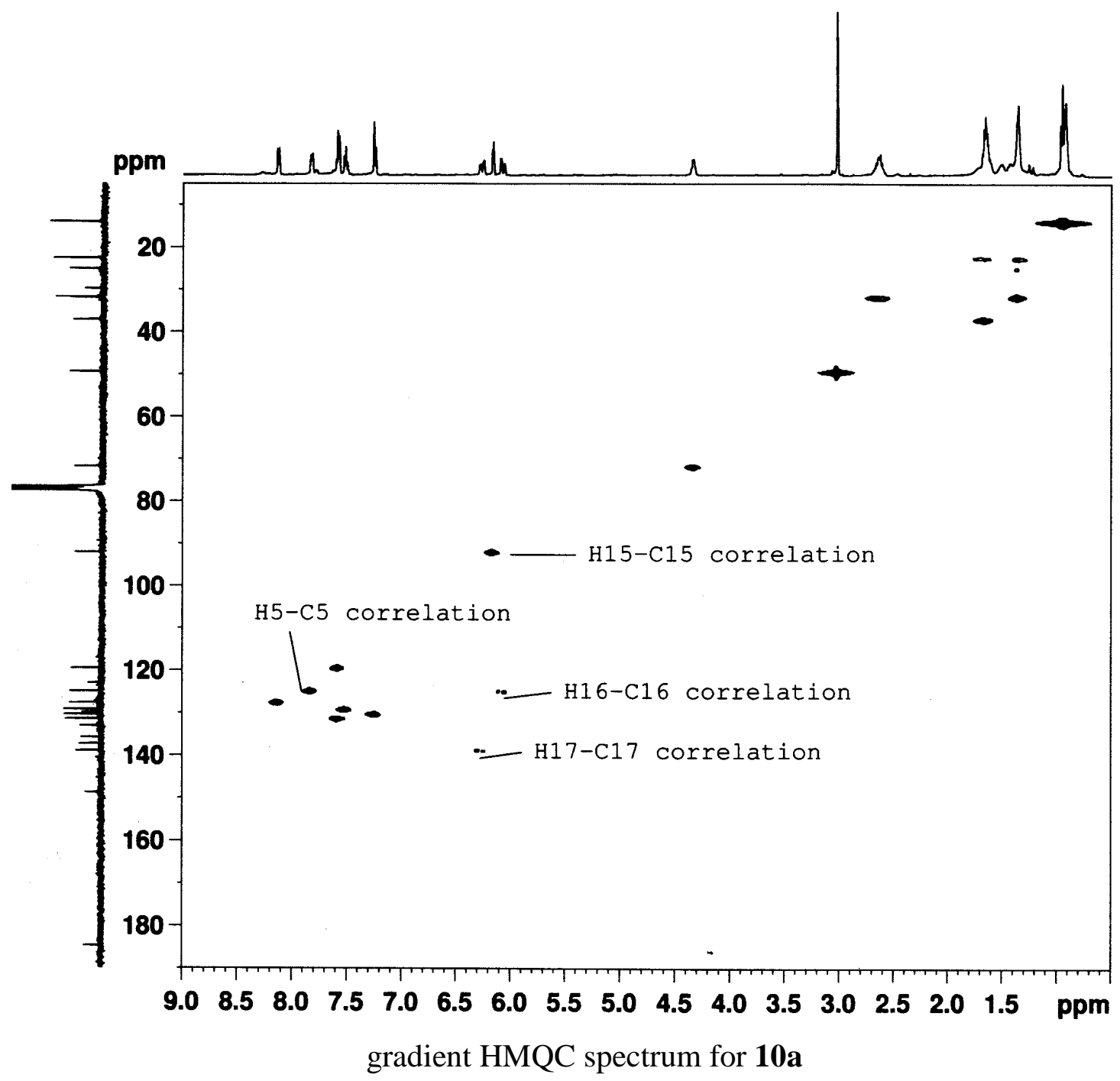




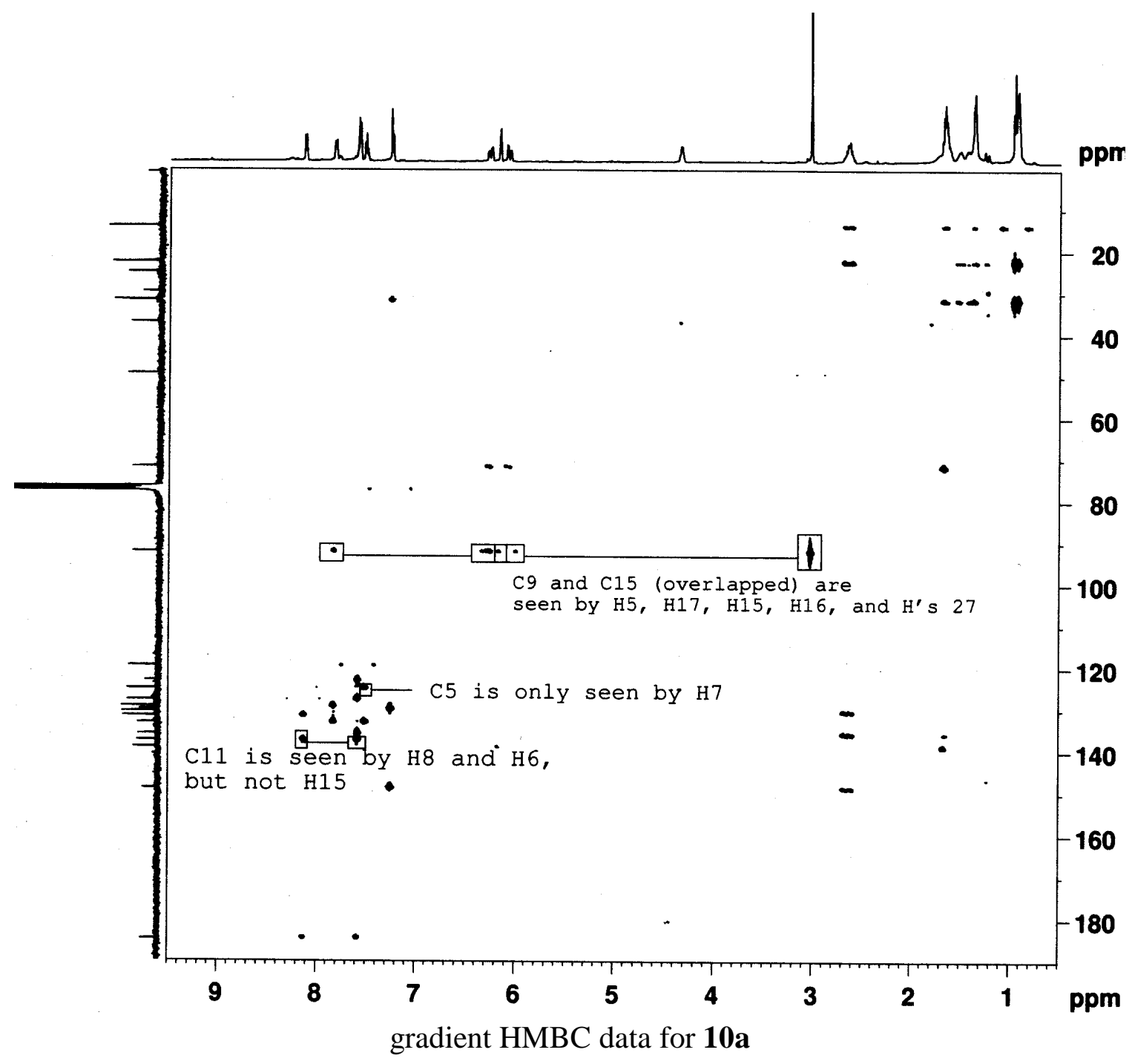




\section{References}

${ }^{1}$ Gaonac'h, O.; Maddaluno, J.; Chauvin, J.; Duhamel, L. J. Org. Chem.,1991, 56, 4045-4048.

${ }^{2}$ Murty, K.; Pal, R.;Datta, K.; Mal. D. Synthetic Comm. 1994, 24, 1287-1292.

${ }^{3}$ Blankespoor, R.L.; Smart, R.P.; Batts, E.D.; Kiste, A.A.; Lew, R.E.; Vasnder, Vilet, M.E. J. Org Chem., 1995, 119, 461-465. 